\title{
The Case for Comparative and Development Public Administration in the Energy Sector
}

\author{
A.U.B. Karunaratne \\ Doctoral Student, Department of Public Administration and Policy, University of Georgia, USA
}

\begin{abstract}
This paper argues for the need for a Comparative and Development Administration framework for the benefit of the energy sector of developingcountries. It emphasizes the need to learn from the challenges faced by the early editions of such frameworks while laying out the different options of aid and assistance available for developing countries to build their local institution and governance structures.
\end{abstract}

\section{Introduction}

Jreisat (2011) [4] defines globalization in terms of linkages, integration, interdependence, and connectedness among economies, people, cultures, and countries. The broad-based globalization is supposed to have the objective of international cooperation to overcome common challenges.

Increasingly, the problems countries or nationstates face transcend the geographical boundaries controlled by them. For example, the haze generated from deforestation in Indonesia affects its neighbors, Singapore and Malaysia from time to time, making the outdoor life unbearable and causing illnesses. International sanctions on major oil exporters such as Venezuela and Iran will not only hurt these producer economies but also the oil importers with a geographic proximity to these countries who rely on relatively cheap oil due to lower transportation costs. It is such a common challenge - the Oil Crisis of 1973 which prompted the formation one of the premier institutions in the energy sector: the International Energy Agency (IEA) by OECD (Organization for Economic Co-operation and Development) countries.

Jreisat (2011) [4] points out some positive impacts of globalization on public administration: the push toward decision-making by negotiation and collaboration rather than self-serving unilateralism, the focus on the culture of performance of the governments, the rebuilding of the image of leadership desired by the people, needing the approach to be more reconciliatory and consultative, and the inclusion of efficiency-drivers such as e-government. However, as he elaborates, global interdependence is forcing the reconsideration of the traditional assumptions, propositions, and principles of public administration, mainly because of the predatory effect of globalization on the independence of national governments. While this effect of reducing the power of national governments increases the leverage people have over their government, it is not necessarily a good thing, as the power of the government elected by the locals has been reduced at the expense of increasing the influence of those who are not elected by the locals. This development could undermine the effectiveness of a nationalist agenda-setting and could hinder the growth of a country no matter how competent the government is.

A prime example is Israel's reluctance to join the IEA despite being qualified to do so since 2010. Rettig (2016) [11] analyzes that, while the membership would help the country in terms of improving its energy security, optimizing efficiency, and promoting environmental legislation and regulations, it hesitates to join because of the general suspicion towards the international community and its organizations fuelled by the strong national security mindset. Another obstacle to membership pointed out by Rettig (2016) is the lack of awareness among policymakers and official government bodies of the positive role the IEA could play in the Israeli energy sector.

The review of Israel's position on IEA membership highlights the important role Comparative and Development Public Administrators could play in facilitating the flow of knowledge and technical expertise from the developed world to the developing world in building national policy and administrative framework to face the modern challenges.

What is Comparative and Development Public Administration?

Jreisat (2011) [4] defines that the Comparative Public Administration is the study of administrative institutions, processes, and behaviors across organizational, national, and cultural boundaries. Riggs (1998) [12] recollects that the Comparative Administration Group (CAG) of the American Society of Public Administration (ASPA), which was chaired by him, came to be identified with work on the administrative problems of developing countries, although its original focus 
was more broadly on the comparative study of all systems of governments. Therefore, the field of Development Administration, which can be considered as a co-field of Comparative Administration, was an invention in the 1950s and 1960s. Development Administration required to be streamlined due to the need of the time to introduce good practices and techniques to developing countries, mushrooming all over the world due to rapid decolonization.

What is Development Assistance?

The OECD (Organization for Economic Co-operation and Development) states that the aid that is flown to the developing world is known as Official Development Assistance (ODA). It is defined as "government aid designed to promote the economic development and welfare of developing countries". It adds that "aid may be provided bilaterally, from donor to recipient, or channeled through a multilateral development agency such as the United Nations or The World Bank. The aid includes grants, 'soft' loans, and the provision of technical assistance". It is estimated that most of the development aid comes from government assistance programs such as the ODA. Development aid and assistance schemes are integral components of Comparative and Development Public Administration programs.

\section{Relevance to Energy Sector}

The Energy Policy and the Public Administration of it are relatively unanchored concepts in developing countries. For instance, China formed its National Energy Administration (NEA) as recently as in 2008, despite previous efforts to put together a national framework to address the concerns in the energy sector. The way a country carries out its energy policy has significant implications on its defense, the quality of its environment, international relations, and most importantly, the well-being of its people. The argument that the developing world has more people and that their carbon footprint would be much higher if they are to develop to achieve the same standard of living of the developed world could be a paramount battle between these two worlds in the near future.
Learning from Early Experiments of Comparative and Development Administration

In the formulation of a framework for Comparative and Development Administration surrounding the energy sector, it would be wise to learn from the experience of early experiments of the field's scholars.

As Riggs (1998) [12] recollects, the work in the field of Development Administration was limited to the period of funding provided by the Ford Foundation starting from 1960 on the condition to work only on Development Administration. Once such funding exhausted, there was very little encouragement to continue with Development Administration. It could have led to the situation which Riggs mentions that sometimes advisors had been sent for field research, training, and consultation with little training on what they are supposed to do. There had been no analysis on the potential for recipient developing countries to funding such a cause. To ensure the sustainability of such a program, it would be paramount to define dedicated revenue sources. For example, if there are any net energy exporters who are OECD member donors, probably a percentage of their national revenue from energy exports could be dedicated.

What is in it for the donor countries to engage in the Comparative and Development Administration framework? Easterly (2014) [1] highlights "the tyranny of experts" contending that "the aid has been used inefficiently to fund inappropriate projects often designed to assist elements of donor economies". While globalization is often perceived as a concept imposed by the West on the rest of the world, it could have a reverse impact as well. The developed world needs the developing world as much. The works of Comparative and Development Administrators builds trust among energy-sector bureaucrats and decision makers among the countries. It enables the donor countries to promote education and training opportunities in the recipient economies which would eventually benefit the investors from donor countries as and when they decide to do business in emerging economies. Comparative Administration is an avenue to "utilize more effectively a comparative perspective that incorporates Western and non-Western systems for developing generalizations and developing best practices" (Jreisat, 2011).

The negative sentiment attached to Comparative Administration was as something imposed on supposedly less developed parts of the world by know-it-all pundits with the Western toolkit. The 
experts in Western countries were ethnocentric for, as Riggs (1998) [12] clarifies, they did not suppose that people in other countries may have had good reasons for doing what they did or that there were people with vested interests in the status quo who would resist changes that might infringe on their privileges. The Expert Approach of the Western consultants was not well received by the academics and practitioners alike in the recipient countries. They would have listened to the external consultants with a more broad mind and would have even advocated for and implemented some of the proposed changes had they been treated as colleagues rather than subordinates. This issue narrows down to the cultural sensitivity of the Westerners during a time when the former colonies had been revitalized by the nationalist pride and had been trying hard to develop a model of their own with the popular support.

Further, Riggs (1998) [12] recounts his experience in Thailand where they feared the negative consequences of foreign-born innovations. Countries with rich civilizations such as China could be hostile to foreign advisory as they, in fact, have had systems of bureaucratic training for thousands of years when the West has developed such systems only during the recent couple of centuries. At the same time, the difference in systems drags the foreign experts to dead-end in some countries, for example, at a time when America focuses on implanting those with private-sector experience in the public sector, some other countries might prefer a system of in-house bureaucrat breeding. Learning from such ideological misalignments and practical hindrances could benefit the successful implementation of a Comparative and Development framework for energy administration.

\section{The Importance of Institutions}

The World Bank researchers such as Burnside and Dollar (2000) have argued that aid and assistance have promoted development and growth in countries with "good" policies and where "countries take ownership" of aid management but not elsewhere. Particularly on the matter of development aid and assistance, it is helpful to study the types of aid in order to evaluate the reasons for the ineffectiveness of certain kinds of aid which results in a mismatch of expectations between the donors and the recipients. Radelet, Clemens, and Bhavnani (2005) [9] point out that "not all aid is alike" and "some types of aid have a much bigger impact on growth and develop- ment than others - possibly why some studies examining aggregate aid find weak results". They categorize the aid related to energy generation and supply as early-impact aid, but the aid related to policy and administrative management as late-impact aid. It would be important to look into what could be the groundwork needed for the success of a Comparative and Development Administration framework.

There is often a complaint by aid recipient countries of development aid in general that it is unfair to include a condition of aid to build a sound institutional framework within the recipient country. The definition of an institution could be ambiguous. North (1991) [6] introduces institutions as a humanely devised formal and informal rules and norms that govern and constrain personal and social behavior and shape incentives that enable societies to function in an orderly manner. He also points out that existence and quality of institutions are dependent on their histories. While the essence of North's definition on institutions is much broad and therefore vague, his emphasis on history clarifies the specifics of what he considers as relevant to his context as a researcher of the institutional basis of markets and a scholar in international development: the institutions of governance. It is to be marked that institutions of governance are different from institutions of government. Taking an example from the energy sector, the Ministry of Power and Energy could be an institution of government, the accuracy of energy data or transparency of bureaucrats can be considered as institutions of governance.

\section{Rivals: Washington or Beijing?}

While the work of Comparative and Development administrators took place in a setting where a donor country shares its expertise on development of institutions and management of resources such as international development aid and assistance with a recipient country, the broader focus on institutions in the context of international development was generated by a set of policies popularized in the 1980s and 1990s universally recognized as the Washington Consensus. It refers to a set of broad yet standard policy recommendations provided by the World Bank and other similar institutions to third world nations as prescriptions for development such as: fiscal discipline, growth reorientation of public expenditures, tax reforms, competitive exchange rates, trade liberalization, deregulation, and legally securing property rights (Rodrik, 2006 [13]). 
Much of this set of policies are applicable to the energy sector.

As a more refined yet alternative version to the Washington Consensus, Hausmann, Rodrik, and Velasco (2005) [2] came up with the growth diagnostic approach which focuses on treating the binding constraints found in developing nations. For example, the unfavorable geographic location of landlocked countries such as Nepal or Bhutan could be binding constraints when it comes to access to energy sources as ground transportation of crude oil could be extremely costly.

Proposals such as that of Justin Yifu Lin (2012) [5] can be considered elements of the Beijing Consensus (Ramo, 2004 [10]), the chief rival to Washington Consensus. It is a proposition inspired by Deng Xiaoping's open economic policies with a tight political control which aided China to rise as an economic powerhouse post-1978. Ramo (2004) [10] describes that the secret behind China's rapid economic development was political authoritarianism rather than the improved quality of its institutions. While the democracydriven Washington Consensus emphasizes on the importance of sound institutions and development aid on economic growth, the Beijing Consensus focuses mainly on the elements of human development, which is essential to attracting foreign direct investment which in turn creates greater wealth for the recipient country. An educated, skillful, and healthy workforce is essential to wooing the investors.

\section{Conclusion}

When choosing between the rival consensuses, developing countries should look in to access to funding as well as to management and technical expertise that comes with them. While there are alternative funding sources to OECD such as the China-based Asian Infrastructure Investment Bank (AIIB), it would be important to assess whether such funding comes with a credible assistance scheme. It is important to note that the availability of funding alone is not sufficient for the success of Comparative and Development Administration frameworks. The transfer of expertise, provided the donor countries have expertise in synthesizing energy sector policies and carrying out their administration, is at the core of these programs. Why the countries who subscribe to the Washington Consensus emphasize on institution-building as the pinnacle of requirements to qualify for aid is because such programs would drive to failure should there be no accountability and transparency on the side of the recipient country. However, the developing countries should decide whether they should be waiting for such funding until they qualify by building an advanced institutional set-up while assessing alternative funding and assistance to develop their energy sectors.

\section{References}

1. Easterly, William. 2014. The Tyranny of Experts: Economists, Dictators, and the Forgotten Rights of the Poor. New York: Ingram Publisher Services.

2. Hausmann, Ricardo, Rodrik, Dani, Velasco, Andres. 2005. "Growth Diagnostics." Accessed at:

3. https://growthlab.cid.harvard.edu/files/growthlab/files/growth-diagnostics.pdf

4. Jreisat, Jamil. 2012. Globalism and Comparative Public Administration. Boca Raton, Florida: CRC Press, Taylor \& Francis Group.

5. Lin, Justin Yifu. 2012. New Structural Economics: A Framework for Rethinking Development and Policy. Washington D.C.: The World Bank.

6. North, Douglass C. 1991. Institutions. The Journal of Economic Perspectives 5(1): 97-112.

7. Organization for Economic Co-operation and Development. 2017. "Aid to developing countries rebounds in 2013 to reach an all-time high." Accessed at:

8. http://www.oecd.org/newsroom/aid-to-developing-countries-rebounds-in-2013-to-reach-anall-time-high.htm

9. Radelet, Steven, Clemens, Michael, and Bhavnani, Rikhil. 2005. Aid and Growth. Finance and Development 42(3).

10. Ramo, Joshua Cooper. 2004. The Beijing Consensus. London: The Foreign Policy Centre.

11. Rettig, Elai. 2016. Limits to cooperation: why Israel does not want to become a member of the International Energy Agency. Israel Affairs. 22(2): 512-527.

12. Riggs, Fred W. 1998. Public Administration in America: Why Our Uniqueness is Exceptional and Important. Public Administration Review. 58(1): 22-31.

13. Rodrik, Dani. 2006. Goodbye Washington Consensus, Hello Washington Confusion? A Review of the World Bank's Economic Growth in the 1990s: Learning from a Decade of Reform. Journal of Economic Literature XLIV: 973-987. 